\title{
Occurrence and Spread of Fire Blight Pathogen (Erwinia amylovora) on Spontaneous and Ornamental Plants in Yugoslavia
}

\author{
M. ARSENIJEVIĆ 1,3 , G. JOVANOVIĆ 2 and V. GAVRILOVIĆ 3 \\ ${ }^{1}$ Faculty of Agriculture, Institute for Plant Protection, 21 000, Novi Sad, Yugoslavia \\ ${ }^{2}$ Agricultural Center, "Leskovac", 16000, Leskovac, Yugoslavia \\ 3Institute for Plant Protection and Environment, 11040, Belgrade, Yugoslavia
}

During a ten-year-investigation on the occurrence and spread of fire blight (Erwinia amylovora) pathogen on spontaneous and ornamental plants in Yugoslavia, the pathogen was found only on hawthorn, wild pear and firethorn. No bacterium was isolated from others species among these two groups of hosts.

Keywords: Fire blight, Erwinia amyvolora, ornamental plants, spontaneous flora.

By its frequent occurrence and infection of high intensity Erwinia amylovora (Burrill) Winslow et al. drew attention in Yugoslavia mostly as a pathogen of Pomaceous fruit trees. At first it was found on quince and pear and later on medlar and apple trees (Arsenijević et al., 1991; Panić and Arsenijević, 1993, 1996).

Frequent and severe occurrence of Erwinia amylovora on Pomaceous fruit trees in Yugoslavia, and weak or none on ornamentals and on plants from spontaneous flora (except hawthorn) drew our attention to try to find pathogen presence also on other ornamentals and spontaneously growing species and to prove its occurrence experimentally.

\section{Materials and Methods}

The plant species examined and samples collecting

Between 1989 and 1999 various plant species were examined and samples for bacteriological tests in laboratory were collected. All samples from spontaneous and ornamental flora resembling to fire blight symptoms were collected.

\section{Isolation of the pathogen}

The isolation of the bacterium was carried out by usual procedure on sucrose nutrient agar (SNA) medium (Klement et al., 1990). No bacterial colonies growth after the isolations of the pathogen proved the lack of E. amylovora in the tissues of the plant species investigated, although the symptoms similar to fire blight bacterium were present among certain species of the samples collected. Additional isolation of the fungi on potato dextrose agar (PDA) was carried out in order to obtain reliable data. 
Check of pathogenicity and identification of the bacterium

Isolates of E. amylovora were tested by using basic methods of identification such as: tobacco (Klement, 1963), Pelargonium hypersensitivity (Arsenijević et al., 1991), Gram differentiation using 3\% KOH (Suslow et al., 1982; loc. cit. Arsenijević, 1997), growth characteristics on Crosse-Goodman's (CG) medium, lack of fluorescence on King's medium B, inoculation of immature pear (cv. Williams) and plum (cv. Stanley) fruits and the hosts from which the bacterial strains were isolated (Klement et al., 1990; Arsenijević, 1997). Slide agglutination test was carried out by the standard procedure (Klement et al., 1990) using immune serum produced by authentic E. amylovora strain.

\section{Results}

Spontaneous flora (Fig. 1)

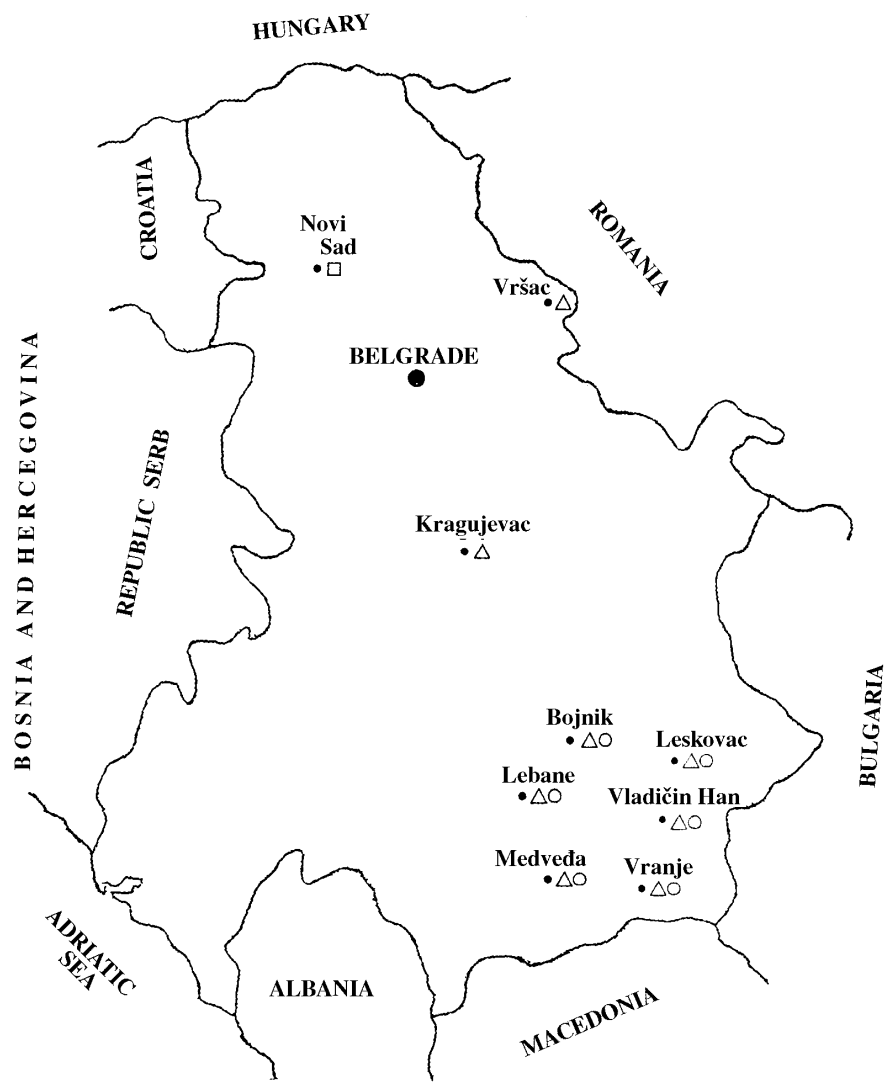

Fig. 1. E. amylovora on hawthorn $(\triangle)$, firethorn $(\square)$ and wild pear $(\bigcirc)$ in Yugoslavia 
Among the samples collected from spontaneous flora only wild pear (Pyrus piraster Burgs.) and hawthorn (Crataegus monogyna Jacq.) manifested positive results. From the samples of other species: mountainash - Sorbus domestica L., sloe plum Prunus spinosa L., wild apple - Malus silvestris Miller, etc. there was no growth of bacterial colonies or the colonies of fungi were grown on PDA.

In the main tests of identification the isolates of bacteria originating from wild pear and hawthorn manifested all properties typical for E. amylovora. The colonies on SNA medium were whitish-cream, levan type and crateorous on CG medium; the bacteria were Gram negative, asporogeneous and rod-shaped. In contrast to the Pseudomonas syringae pv. syringae (J-50) check strain, isolates of $E$. amylovora did not produce green fluorescent pigment on King' s medium B, formed droplets of bacterial exudate on immature pear and plum fruitlets artificially inoculated and they reacted positively with E. amylovora antiserum in agglutination test.

\section{Ornamental plants (Fig. 1)}

Many species of ornamental plants were investigated, whether they were cited in the literature as E. amylovora hosts or not (june-berry - Amelanchier ovalis Medic., flowering japanese quince - Chaenomeles japonica (Thumb.) Lindr. ex Spach, rock spray cotoneaster - Cotoneaster horisontalis Decne., loquat - Eryobotrya japonica (Thumb.) Lindl., box-free - Buxus sempervirens L., golden bell - Forsythia intermedia Zab., cherry laurel - Prunus laurocerasus L., firethorn - Pyracantha coccinea Roem.), because, they express fire blight like symptoms. However, E. amylovora was isolated only from firethorn (Pyracantha coccinea Roem.).

The pathogen was found for the first time on firethorn in 1997 in the center of Novi Sad city, where these plants were cultivated for ornamental purpose. In the following year (1998) the fire blight disease was registered in other part of the city in another two localities. All bacterial isolates originating from firethorn manifested main characteristics typical for E. amylovora bacterium as it was given in the chapter "Spontaneous flora".

However, in the absence of E. amylovora on SNA medium, several fungal colonies appeared on PDA: Leucostoma, Nectria, Monilinia, Phomopsis, etc. were isolated from necrotic tissues of the species, showing fire blight like symptoms.

\section{Discussion}

Fire blight (E. amylovora) bacterium is widely spread and economically important pathogen of Pomaceous trees in Yugoslavia (Arsenijević et al., 1991; Panić and Arsenijević, 1993, 1996). Among spontaneous flora, the infection was proved for the first time on hawthorn and wild pear in 1991 (Panić and Arsenijević, 1996).

On ornamental plants cultivated in Yugoslavia, E. amylovora was not found. Only in the summer of 1997, weak infection was found on firethorn in the center of Novi Sad (Gavrilović and Arsenijević, 1998). The infection spread slowly, and the expansion of the pathogen was stopped by mechanical measures. However, fire blight on hawthorn 
and wild pear occurred more frequently (Fig. 1) in different localities (Arsenijević and Panić, 1996; Arsenijević and Gavrilović, 1998).

It can be concluded that hawthorn, in addition to Pomaceous plants (pear, quince, apple and medlar trees), is a frequent and susceptible host of E. amylovora in Yugoslavia. This is also proved in other countries (Graberg, 1993; Jorgensen, 1978; Billing 1981, etc.) On the contrary, except for Novi Sad, firethorn as well as many other ornamental plants were free from the fire blight disease (Arsenijević and Panić, 1996).

However, Cotoneaster, Crataegus, Pyracantha, Stranvaesia and Sorbus in many countries manifested extreme susceptibility to E. amylovora. Due to this, many ornamental shrubs in parks and gardens or elsewhere have to be eradicated and destroyed (Garrett, 1990; Meijneke, 1975; van der Zwet and Keil, 1979; IWG Reporter, 1991)

Such a rare and weak occurrence of Erwinia amylovora pathogen on firethorn and frequent and severe infection on Pomaceous trees and hawthorn in Yugoslavia deserves full attention. Therefore, further investigations of E. amylovora on ornamentals and spontaneous flora, are of great interest.

\section{Acknowledgments}

We thank Mrs Dušanka Savić and Mr. Milovan Katić for technical assistance.

\section{Literature}

Arsenijević, M. (1997): Bacterial Plants Diseases. 3rd Edition, S-Print, Novi Sad, 576 pp. (in Serbian with English contents).

Arsenijević, M. and Gavrilović, V. (1998): First report of Erwinia amylovora on hawthorn in the region Shumadia. Plant Protection Reporter (Biljni Lekar) 6, 546-550, Novi Sad (in Serbian with English abstract).

Arsenijević, M. and Panić, M. (1996): Host Plants of the Erwinia amylovora bacterium so far established in Yugoslavia. Plant Protection (Zaštita bilja), Belgrade, 219, 57-66 (in Serbian with English summary).

Arsenijević, M., Panić, M. and Antonijević, D. (1991): Fire blight of Pomaceous fruit trees in Yugoslavia. Plant Protection (Zaštita bilja) 196, 87-97, Belgrade (in English with Serbian summary).

Billing, E. (1981): Weather analysis and fire blight in different climates. Acta Horticulturae 117, 45-48.

Garrett, C. M. E. (1990): Control of fire blight. In: Fire Blight of Pomoideae. Applied Research in Europe (1978-1988), Cord. J. P. Paulin. Commission of the European Communities, Luxemburg, pp. 54-78.

Gavrilović, V. and Arsenijević, M. (1998): Firethorn - A new host of Erwinia amylovora bacterium for our country. Plant Protection Reporter (Biljni Lekarz) 1, 52-55, Novi Sad (in Serbian with English abstract).

Graberg, M. K. (1993): Fireblight in Sweden. Experience and Further Work. Acta Horticulturae, 338, 33-36.

International Working Group (IWG) on Fire Blight Research (1991): Present Status and New Occurrences of Fire Blight. Newsletter, January, 1991, 4-22. (Ed. van der Zwet) Kearneysville, West Virginia, USA.

Jorgensen, H. A. (1978): Fire blight control in Crataegus by clipping. Acta Horticulturae, 86, 69-70.

Klement, Z. (1963): Rapid detection of pathogenicity of phytopathogenic pseudomonads. Nature 199, 299-300.

Klement, Z., Rudolph, K. and Sands, D. C. (eds) (1990): Methods in Phytobacteriology. Akadémiai Kiadó, Budapest, $568 \mathrm{pp}$.

Meijneke, C. A. R. (1975): Prevuur-bacterievuur. Netherlands. Plant Protection Serv. Ybk., 46-52. 
Panić, M. and Arsenijević, M. (1993): Outbreak, spread and economic importance of fire blight pathogen (Erwinia amylovora) in Yugoslavia. Acta Horticulturae 338, 89-96.

Panić, M. and Arsenijević, M. (1996): Erwinia amylovora - Fire Blight Pathogen of Fruit Trees and Ornamental Plants. Monographic study. S-Print, Novi Sad, Fruit and Vegetable Assotiation D. D., Belgrade and Faculty of Agriculture, Novi Sad, 419 pp. (in Serbian with English summary), pp. 33-48, 76-84, 93-104.

van der Zwet, T. and Keil, L. H. (1979): Fire Blight. A bacterial disease of Rosaceous plants. U. S. Government Printing Office, Washington D. C., pp. 10-19, 19-21, 27, 29-37. 